\title{
Developmental changes in rat blood choline concentration
}

\author{
Steven H. ZEISEL and Richard J. WURTMAN \\ Laboratory of Neuroendocrine Regulation, Department of Nutrition and Food Science, \\ Massachusetts Institute of Technology, Cambridge, MA 02139, U.S.A.
}

(Received 19 March 1981/Accepted 13 May 1981)

\begin{abstract}
1. Serum choline concentration in the newborn rat is extremely high and declines as the rat matures until adult values are attained at 20 days of age. 2 . Rat milk is a rich source of choline, and rat pups denied access to milk had significantly lower serum choline concentrations than did fed littermates. We conclude that dietary intake of choline contributes to the maintenance of high serum choline concentrations in the neonatal rat. 3. In vivo, choline disappears with a half-life of $70 \mathrm{~min}$. It is converted into betaine, phosphocholine and phosphatidylcholine. The rate of phosphocholine formation is identical in 3- and 10 -day-old rats $(3.3 \mu \mathrm{mol} / \mathrm{h})$, whereas the rate of betaine formation is slower in younger animals $(0.15 \mu \mathrm{mol} / \mathrm{h}$ at 3 days versus $0.69 \mu \mathrm{mol} / \mathrm{h}$ at 10 days). In vitro, choline oxidase activity [choline dehydrogenase (EC 1.1.99.1) and betaine aldehyde dehydrogenase (EC 1.2.1.8)] increased between birth and 40 days of age. The age-related acceleration in choline's conversion into betaine probably tends to diminish unesterified choline concentration in the rat.
\end{abstract}

Plasma choline constitutes an important source of choline both for neuronal acetylcholine synthesis (Cohen \& Wurtman, 1975, 1976; Haubrich et al., 1976), and for producing aminophospholipids such as phosphatidylcholine, sphingomyelin and the choline-plasmalogens (Kennedy \& Weiss, 1956; Sundler et al., 1972; Epstein \& Farrell, 1975). Plasma choline concentration is much higher in newborn humans, rats or rabbits than it is in adults (Zeisel et al., 1980). We now describe the agerelated changes in blood choline concentration in the rat, and discuss the effects of diet, organ uptake and metabolism on blood choline concentrations.

\section{Experimental}

Sprague-Dawley rats (Charles River Laboratories, Wilmington, MA, U.S.A.) were housed singly and exposed to ambient temperatures of $24^{\circ} \mathrm{C}$, and to light $\left(300 \mu \mathrm{W} / \mathrm{cm}^{2}\right.$; Vitalite; Durotest Corp., North Bergen, NJ, U.S.A.) for 12h/day (08:0020:00h). They were allowed free access to food (Charles River Rat-Mouse-Hamster Maintenance Formula: $23 \%$ protein, $4.5 \%$ lipid, $72 \%$ carbohydrate, $0.183 \%$ free choline) and water. Newborn rats of both sexes were obtained from females of timed gestation. On the day of birth, pups were randomly distributed among litters and allowed free access to a dam and rat chow. At each postnatal age rats were decapitated; infants were selected from separate litters, decreasing litter size uniformly.

Tissue samples collected to determine choline metabolite concentrations were rapidly excised and quick-frozen between aluminum blocks precooled in liquid $\mathrm{N}_{2}$. All tissue specimens were stored at $-80^{\circ} \mathrm{C}$ until used.

Blood samples collected for subsequent choline determinations were immediately placed on ice, allowed to clot and then centrifuged at $1200 \mathrm{~g}$ for $10 \mathrm{~min}$ at $4^{\circ} \mathrm{C}$. Supernatant serums were withdrawn by aspiration and frozen at $-80^{\circ} \mathrm{C}$ until assayed.

\section{Experimental design}

Choline concentration was analysed in serum samples collected at the time of birth (zero h), $6 \mathrm{~h}$ after birth and at midday each day thereafter. In studies investigating the strain specificity of developmental changes in serum choline, Long-Evans rat pups (Charles River Laboratories) killed at 1 or 3 days of age were compared with Sprague-Dawley pups of similar age. The effect of starvation on serum choline concentration was investigated by using Sprague-Dawley rat pups at 3 or 7 days of age; 10 rat pups were placed with a non-lactating dam (which had delivered 1 month previously) and 10 pups were placed with a lactating dam. At the end of $7 \mathrm{~h}$, rat pups were killed. All fed rats maintained or gained weight $(0-0.7 \mathrm{~g})$, whereas all starved 
rats lost weight $(0.1-0.3 \mathrm{~g})$. Stomach contents were also examined; all fed rats, as well as several starved rats, still had milk in their stomachs. The choline content of rat milk was measured in samples of milk obtained by manual expression from rat dams previously injected subcutaneously with $0.4 \mathrm{i}$.u. of ocytocin dissolved in normal saline (Sigma Chemicals, St. Louis, MO, U.S.A.) and anaesthetized with ether.

In studies of choline-metabolizing capacity, rat pups (3 or 10 days old) were injected intraperitoneally with choline chloride $(25 \mathrm{mg} / \mathrm{kg}$ body wt., containing $2 \mu \mathrm{Ci}$ of $\left[\mathrm{Me}^{-}{ }^{3} \mathrm{H}\right]$ choline (New England Nuclear Corp., Boston, MA, U.S.A.). Rats were then killed after $0,15,30$ or $60 \mathrm{~min}$ and immediately homogenized (Waring Commercial Blender at high speed) in $200 \mathrm{ml}$ of ice-cold $25 \% 1 \mathrm{M}$-formic acid in acetone. A portion of this homogenate, solubilized in NCS (Amersham, Arlington Heights, IL, U.S.A.), was mixed with $15 \mathrm{ml}$ of BetaFluor (National Diagnostics, Somerville, NJ. U.S.A.) for liquidscintillation counting (Beckman LS-7500). C.p.m. were converted into d.p.m. using the $\mathrm{H}$ number. Another portion of the homogenate was centrifuged at $1200 \mathrm{~g}$ for $10 \mathrm{~min}$ at $4^{\circ} \mathrm{C}$; the supernatant fluid was withdrawn by aspiration, freeze-dried and resuspended in chloroform/methanol/water $(4: 2: 1$, by vol.). A portion of the aqueous phase was subjected to paper electrophoresis to determine choline and metabolites as described below.

In studies of choline oxidase, rats of various ages were decapitated and liver biopsies obtained, quickfrozen between blocks of aluminum precooled in liquid $\mathrm{N}_{2}$, and stored at $-80^{\circ} \mathrm{C}$ until assayed.

\section{Biochemical determinations}

Choline was assayed in tissues using a modified method of Goldberg \& McCaman (1973). Tissue samples (brain, liver etc.) were sonicated (W-255R; Heat Systems Ultrasonics, Plainview, Long Island, NY, U.S.A.) for $1 \mathrm{~min}$ in $10 \mathrm{vol}$. of $15 \% 1 \mathrm{M}$-formic acid in acetone. Samples were centrifuged at $1200 \mathrm{~g}$ for $10 \mathrm{~min}$ at $4^{\circ} \mathrm{C}$ and the supernatant fluids were withdrawn by aspiration. Serum samples were not subjected to such pretreatment. After extraction with tetraphenylboron dissolved in heptanone, and back extraction into $0.4 \mathrm{M}-\mathrm{HCl}$, choline was allowed to react with [ $\left.{ }^{32} \mathrm{P}\right] \mathrm{ATP}$ (Amersham) in the presence of choline kinase (EC 2.7.1.32; Sigma Chemicals), forming phosphocholine. This was isolated by anionexchange chromatography [AG1 resin (X8, 200400 mesh, formate form); Bio-Rad, Richmond, CA, U.S.A.] and its radioactivity determined by scintillation counting. Choline concentrations were determined using a set of external standards subjected to the same extraction and reaction procedures. All data were also corrected for recovery by using internal $\left[\mathrm{Me}^{-3} \mathrm{H}\right]$ choline standards.
Phosphatidylcholine in milk samples was hydrolysed and the choline content then measured by using the above radioenzymic assay. Milk samples were added to equal volumes of chloroform and methanol, mixed and centrifuged. A portion of the chloroform phase was then applied to a silica-gel t.l.c. plate (LK5D; Whatman Corp., Clifton, NJ, U.S.A.). The plate was developed in chloroform/ methanol/water (65:30:4, by vol.) and segments were identified using external standards stained with $\mathrm{I}_{2}$ vapour. The segments that co-chromatographed with phosphatidylcholine were scraped off and hydrolysed in $6 \mathrm{M}-\mathrm{HCl}$ at $80^{\circ} \mathrm{C}$ for $1 \mathrm{~h}$. A portion of the hydrolysate was then dried, subjected to extraction and assayed for choline as described above.

Sphingomyelin was extracted from milk and purified by using the t.l.c. technique described for the phosphatidylcholine assay. The segments that cochromatographed with sphingomyelin were scraped off and incubated with sphingomyelinase (0.1 unit; Boehringer Mannheim, Indianapolis, IN, U.S.A.) in the presence of $0.1 \%$ Triton $\mathrm{X}-100$ (Doe and Ingalls, Medford, MA, U.S.A.) and $\mathrm{MgCl}_{2}$ in Tris buffer ( $\mathrm{pH}$ 7.0). Choline extracted from a portion of this incubation mixture was assayed as described above.

Choline metabolites were isolated by using paper electrophoresis at constant voltage $(500 \mathrm{~V})$ and $0.75 \mathrm{M}$-acetic acid/0.75 $\mathrm{M}$-formic acid buffer ( $\mathrm{pH} 2$ ) (Potter \& Murphy, 1967). Segments were identified by using $I_{2}$ vapour and were eluted with water. With this method, choline migrated $16.8 \mathrm{~cm} / \mathrm{h}$, betaine aldehyde $15.5 \mathrm{~cm} / \mathrm{h}$, betaine $11.0 \mathrm{~cm} / \mathrm{h}$ and phosphocholine $7.8 \mathrm{~cm} / \mathrm{h}$.

Choline oxidase activity was measured in $10 \%$ $(\mathrm{w} / \mathrm{v})$ homogenates of liver prepared in $0.2 \mathrm{M}$-sodium phosphate buffer ( $\mathrm{pH}$ 7.4). Of this homogenate, $500 \mu \mathrm{l}$ was incubated with $2 \mathrm{mM}$-choline chloride (containing $\left[\mathrm{Me}^{-3} \mathrm{H}\right]$ choline; New England Nuclear Corp.) for $15 \mathrm{~min}$ at $37^{\circ} \mathrm{C}$ in an atmosphere of pure $\mathrm{O}_{2}$. The reaction was stopped by addition of $500 \mu$ l of chloroform/methanol $(1: 1, \mathrm{v} / \mathrm{v})$. A portion of the aqueous phase was withdrawn by aspiration and subjected to paper electrophoresis as described above. The betaine segment was eluted with water and radioactivity was determined by scintillation counting. The specific radioactivity of choline in incubation mixtures was calculated by using choline concentrations assayed as previously described. Protein was measured by the method of Bradford (1976). Betaine formation was linear for more than 30 min under the conditions described.

\section{Results}

In the rat, serum choline concentrations were greatest at birth $(65 \mu \mathrm{M}$; greater than 6 times adult 




Fig. 1. Serum choline concentration in the rat Sprague-Dawley rat pups were decapitated at various ages. Blood was handled as described in the Experimental section. Serum was assayed for free choline by using a radioenzymic technique (see the Experimental section). Data are expressed as means \pm S.E.M. for 10 pups at each age.

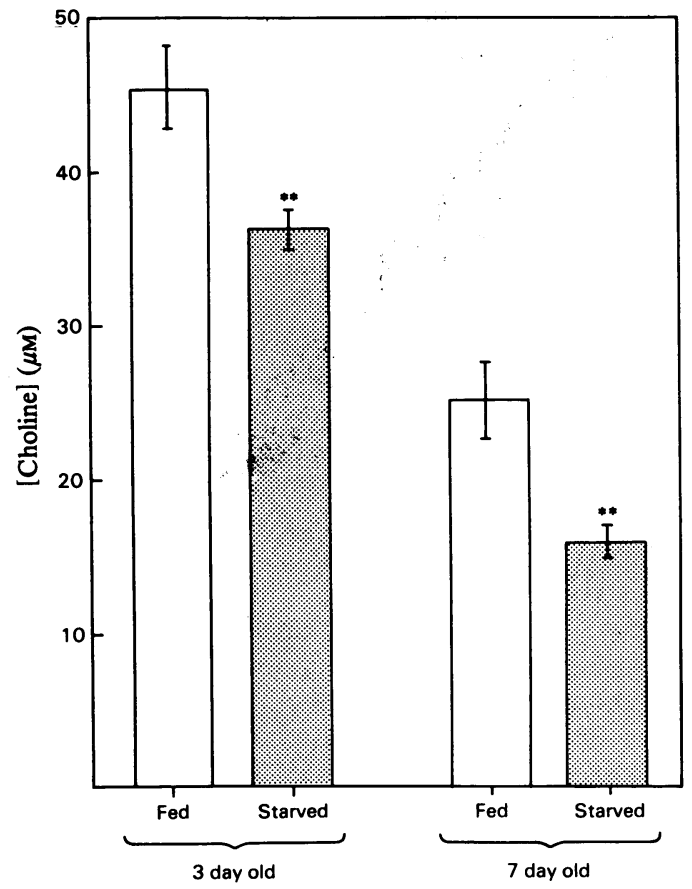

Fig. 2. Effect of starvation on rat serum choline concentration

Sprague-Dawley rat pups at 3 and 7 days of age were placed with either a lactating or a non-lactating dam for $7 \mathrm{~h}$. At the end of this period, rats were decapitated and blood was collected and handled as described in the Experimental section. Choline was assayed by a radioenzymic technique (see the Experimental section). Data are expressed as means \pm S.E.M. for 10 rats per point. ${ }^{* *} P<0.01$ compared with fed group. values) and remained significantly higher than adult values until after 15 days of age $(P<0.01$, one-way analysis of variance; Fig. 1). These results were duplicated in experiments in which litter size was kept constant at each age (results not shown). Serum choline concentrations in 1- and 3-day-old LongEvans rats did not significantly differ from those of similarly aged Sprague-Dawley rats (Student's $t$ test).

Rats denied aceess-tomilk for $7 \mathrm{~h}$ had significantly lower serum choline concentrations than fed rats at both 3 and 7 days of age $(P<0.01$, Student's $t$ test; Fig. 2). The choline in rat milk was present as free

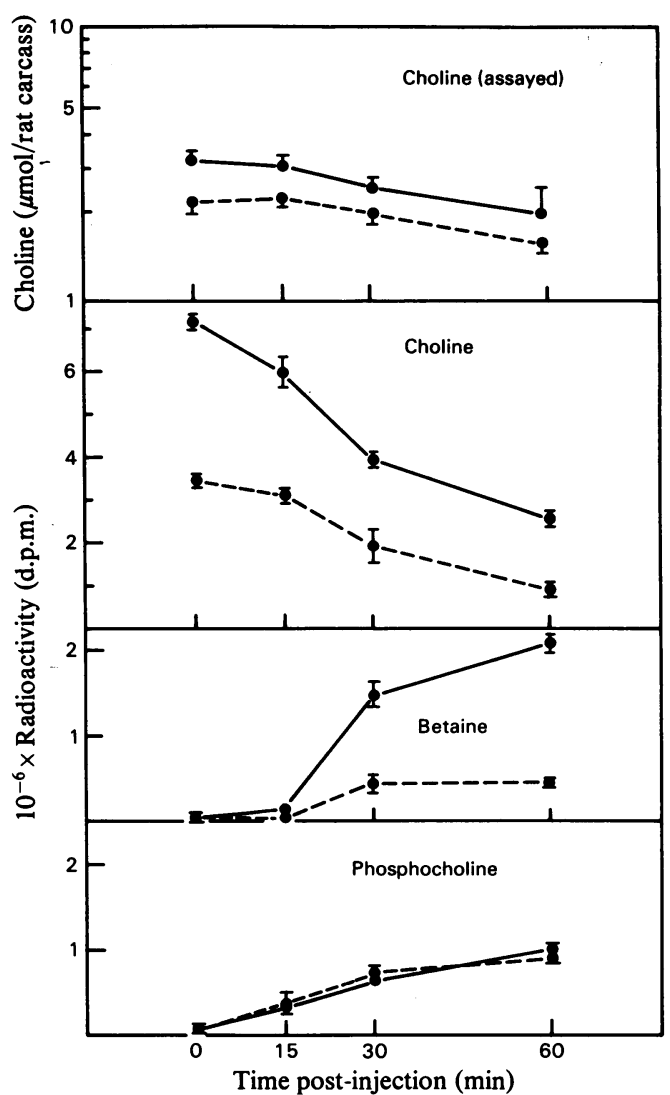

Fig. 3. Choline-metabolizing capacity in the rat Rat pups (3 days old, -- -10 days old, - ) were injected with choline chloride $(25 \mathrm{mg} /$ $\mathrm{kg}$ of body wt., containing $2 \mu \mathrm{Ci}$ of $\left[\mathrm{Me}^{-3} \mathrm{H}\right]-$ choline). Rats were killed at $0,15,30$ or $60 \mathrm{~min}$ and immediately homogenized. A portion of homogenate was assayed for free choline using a radioenzymic technique as described in the Experimental section. Another portion was subjected to paper electrophoresis and radioactivity in choline, betaine and phosphocholine was determined by liquid-scintillation counting. Radioactivities on day 10 were corrected to the same initial specific radioactivity as on day 3 for purposes of comparison. Data are means \pm S.E.M. for three rats at each point. 
base (225 $\pm 25 \mu \mathrm{M}$; mean \pm S.D.), as a constituent of phosphatidylcholine $(553 \pm 18 \mu \mathrm{m}$; mean \pm S.D. $)$ and as a constituent of sphingomyelin $(483 \pm 132 \mu \mathrm{M}$; mean \pm S.D.).

Choline, determined by assay, disappeared after it was injected at rates approximated by using firstorder rate constants (Fig. 3). The half-life for choline was $70 \mathrm{~min}$ within the bodies of 3- or 10-day-old rats. Radioactive label was redistributed into the choline metabolites, betaine and phosphocholine, and into compounds insoluble in acetone, which included the phospholipids. Radioactivity was almost completely recovered within the rat carcass (only at time $60 \mathrm{~min}$ was choline excreted in significant amounts in urine). Comparing the specific radioactivity of choline in the injection bolus with the specific radioactivity observed in the rat carcass at the instant of injection (calculated by linear regression analysis) revealed that injected choline was diluted by an endogenous pool of choline. In the 3-day-old, this pool amounted to $1.60 \mu \mathrm{mol}$, whereas in the 10-day-old it was $1.22 \mu \mathrm{mol}$. Rats at both ages converted the same amount of injected choline into phosphocholine $(3.3 \mu \mathrm{mol} / \mathrm{h}$, calculated using the initial specific radioactivity of choline; Fig. 3); 3-day-old rats converted injected choline into betaine at a slower rate than did 10-day-old rats $(0.15 \mu \mathrm{mol} / \mathrm{h}$ and $0.69 \mu \mathrm{mol} /$ $\mathrm{h}$ respectively, calculated using the initial specific radioactivity of choline; Fig. 3). At both ages



Fig. 4. Choline oxidase activity in total rat liver Liver homogenates were incubated at $\mathrm{pH} 7.4$ with $\left[\mathrm{Me}^{14} \mathrm{C}\right]$ choline $(2 \mathrm{mM})$ for $15 \mathrm{~min}$ at $37^{\circ} \mathrm{C}$ Betaine was extracted with chloroform/methanol/ water, and was isolated using paper electrophoresis. Protein was determined using the method of Bradford (1976). Data are expressed as means \pm S.E.M. for 3 rats at each age.
$1.7 \mu \mathrm{mol}$ of choline $/ \mathrm{h}$ was recovered in material precipitated by acetone (presumably in the form of lecithin).

Choline oxidase [choline dehydrogenase (EC 1.1.99.1) and betaine aldehyde dehydrogenase (EC 1.2.1.8)] activity within liver homogenates increased between birth and 40 days of age. On the first day of life, $0.5 \mu \mathrm{mol}$ of betaine was formed $/ \mathrm{min}$ per $\mathrm{g}$ of liver protein, whereas at 40 days almost $5.0 \mu \mathrm{mol}$ of betaine was formed ( $900 \%$ increase). If choline oxidase activity is expressed per total liver weight, the increase in activity is even more pronounced (Fig. 4). In liver homogenates from both 1- and 60-day-old rats, betaine formation proceeded at half-maximal rates in the presence of $0.7 \mathrm{mM}$-choline $\left(K_{\mathrm{m}_{\text {(apparent) }}}=0.7 \mathrm{mM}\right)$.

\section{Discussion}

These data show that serum choline concentration in the newborn rat is extremely high, and that it declines as the rat matures (Fig. 1). The changes in serum choline concentration are not restricted to the rat; they are also found in perinatal rabbits and humans (Zeisel et al., 1980).

Rat milk is a rich source of choline and rat pups denied access to milk had significantly lower serum choline concentrations than did fed littermates (Fig. 2). We conclude that dietary intake of choline contributed to the maintenance of high serum choline concentrations in the neonatal rat.

In our studies of choline-metabolizing capacity it is possible that injected choline totally mixes with endogenous choline pools; however, it may be that these pools of choline are isolated (i.e. within cells) and not available for mixing. If we make calculations based on this latter assumption (i.e. convert d.p.m. of choline into $\mu \mathrm{mol}$ of choline using the specific radioactivity of choline in the bolus), choline (assayed) exceeds choline (labelled) at each time point by approximately the amount present in the endogenous pools. In 3-day-old animals this difference at 15,30 and $60 \mathrm{~min}$ averaged $1.43 \pm$ $0.12 \mu \mathrm{mol}$ (mean \pm S.D.; endogenous pool $=$ $1.60 \mu \mathrm{mol})$; in 10-day-old animals the difference averaged $1.24 \pm 0.03 \mu \mathrm{mol}$ (mean \pm S.D.; endogenous pool $=1.22 \mu \mathrm{mol}$ ). This suggests that the endogenous pools of choline are preserved.

Phosphocholine formation from injected choline apparently proceeds at identical rates in both 3- and 10-day-old rats, assuming preservation of choline's specific radioactivity (Fig. 3). Similar conclusions have previously been drawn from studies on isolated liver slices (Weinhold \& Sanders, 1973). Phosphocholine is an important intermediate in the CDPcholine pathway for phosphatidylcholine synthesis (Kennedy \& Weiss, 1956). Choline that has been 
converted into phosphatidylcholine is no longer immediately available as free choline; however, it also has not been irretrievably lost as a future source of free choline since choline can be liberated from phosphatidylcholine by several widely distributed enzymes (MacFarlane et al., 1934; Kates, 1960; Baldwin \& Cornatzer, 1968; Illingworth \& Portman, 1973; Saito \& Kanfer, 1975; Blusztajn \& Wurtman, 1981).

The 10-day-old rat converted four times more choline into betaine than did the 3-day-old (Fig. 3). The oxidation of choline to betaine involves the formation of the intermediate betaine aldehyde; this is catalysed by the enzymes choline dehydrogenase and betaine aldehyde dehydrogenase (Hatefi \& Stiggall, 1976). When betaine formation is measured in crude tissue homogenates, the activities of the two enzyme are lumped together as choline oxidase activity. This enzyme activity is present in several mammalian tissues, including liver (where it is most active) and kidney. It is not present in the brain, muscle or blood of the rat (Bernheim \& Bernheim, 1933, 1938; Mann \& Quastel, 1937; Hatefi \& Stiggall, 1976).

We found a rapid increase in choline oxidase activity of liver homogenates prepared from rat pups older than 20 days (Fig. 4). These increases in activity are not due to changes in the enzyme's affinity for choline. Rat hepatic mitochondrial choline dehydrogenase activity has also been shown to increase markedly postnatally (Weinhold \& Sanders, 1973; Streumer-Svobodova \& Drahota, 1977) and choline oxidase activity in preparations of rat liver slices is lower in foetal (19 days postconception) and neonatal (7 days old) than in adult rats (Weinhold \& Sanders, 1973). Betaine cannot be reduced to form choline; it can, however, donate one of its methyl groups to homocysteine, producing dimethylglycine and methionine, in a reaction catalysed by betaine:homocysteine methyltransferase (EC 2.1.1.5) (Hatefi \& Stiggall, 1976). Although the methyl groups can thereby be re-utilized once the choline has been converted into betaine, its backbone is lost as a future source of free choline. For this reason, the age-dependent acceleration in choline's conversion into betaine probably tends to diminish free choline concentrations in the rat.

As the rat grows its free choline is distributed within an increasing tissue mass. During the first 2 weeks of life its body weight increases from 4.7 to $18.0 \mathrm{~g}$, and the weight of its blood from 0.55 to $1.38 \mathrm{~g}$ (Donaldson, 1924). If the absolute amount of free choline available does not keep pace with this growth, then tissue choline concentrations must drop. We observed that the quantity of free choline in the total body was greater in the 3-day-old than in 10-day-old rats. Thus both an increased volume of distribution, and an absolute decrease in pool size, contribute to the observed decline in blood choline concentrations (Fig. 1).

Although much choline is derived from dietary sources (Wurtman, 1979), some is synthesized endogenously via the sequential methylation of phosphatidylethanolamine (Bremer \& Greenberg, 1961). It is possible that this synthesis proceeds more rapidly in the newborn, resulting in higher blood choline concentrations; however, the data of Hoffman et al. (1979) and our preliminary observations on the activities of the hepatic methylating enzymes suggest that this is not the case (S. H. Zeisel, J. K. Blusztajn \& R. J. Wurtman, unpublished work).

Choline concentration in any tissue is the result of continuously changing inputs and outputs. Our data support the hypothesis that high choline concentrations in neonatal blood reflect the increased dietary intake, slow metabolism and small volume of choline distribution in young animals. The high choline concentrations may act to ensure adequate supplies of this nutrient for several vital biochemical reactions. Acetylcholine synthesis and release are influenced by serum choline concentrations (Cohen \& Wurtman, 1975, 1976; Haubrich et al., 1976). The neonatal blood/brain barrier transports choline into brain readily (Pardridge et al., 1979); therefore, high serum choline concentrations should be reflected in high brain choline, and subsequently in high brain acetylcholine concentrations. The rat is born with fewer than $10 \%$ of the brain cholinergic terminals that it will have as an adult (Ladinsky et al., 1972; Sorimachi \& Kataoka, 1975), yet receptors for acetylcholine are present in numbers similar to those observed in adults (Rotter et al., 1979). One mechanism that could allow smaller numbers of nerve terminals to release 'normal' amounts of neurotransmitter would be to amplify acetylcholine synthesis by making large quantities of choline available to brain.

In some tissues lecithin synthesis is also accelerated in the presence of high choline concentrations (Robbins \& Armstrong, 1976), whereas dietary choline deficiency results in decreased phosphatidylcholine synthesis (Kaytal \& Lombardi, 1978). High serum choline concentration may promote optimal phosphatidylcholine synthesis in the newborn. It is possible that diseases related to decreased phosphatidylcholine production, such as the respiratory distress syndrome of the human newborn (Brumley et al., 1972; Gluck et al., 1972), are in some way related to changes in choline availability.

We thank Dr. S. Magil, Ms. M. Brigida and Mr. J. Spivak for technical assistance. These studies were supported in part by grants from the National Institute of Mental Health (MH-28783), the National Aeronautics 
and Space Administration (NGR-22-009-627) and the Center for Brain Sciences and Metabolism, Charitable Trust. S.H.Z. is a John A. and George L. Hartford Fellow of the John A. Hartford Foundation. Portions of the studies described formed the basis of the Ph.D. thesis of S.H.Z.

\section{References}

Baldwin, J. J. \& Cornatzer, W. E. (1968) Biochim. Biophys. Acta 164, 195-204

Bernheim, F. \& Bernheim, M. L. C. (1933) Am. J. Physiol. 104, 438-440

Bernheim, F. \& Bernheim, M. L. C. (1938) Am. J. Physiol. 121, 55-60

Blusztajn, J. K. \& Wurtman, R. J. (1981) Nature (London) 290, 317-318

Bradford, M. (1976) Anal. Biochem. 72, 248-254

Bremer, J. \& Greenberg, D. (1961) Biochim. Biophys. Acta 46, 205-216

Brumley, G. W., Hudson, W. A. \& Avery, M. E. (1972) Pediatrics 40, 12-17

Cohen, E. L. \& Wurtman, R. J. (1975) Life Sci. 16, 1095-1102

Cohen, E. L. \& Wurtman, R. J. (1976) Science 191, 561-562

Donaldson, H. (1924) The Rat, Wistar Institute Press, Philadelphia

Epstein, M. F. \& Farrell, P. M. (1975) Pediatr. Res. 9, 658-665

Gluck, L., Lulovich, M. V., Eidelman, A. L., Cordero, L. \& Khazin, A. F. (1972) Pediatrics 6, 81-87

Goldberg, A. \& McCaman, R. (1973) J. Neurochem. 20, 1-8

Hatefi, Y. \& Stiggal, D. (1976) Enzymes 3rd Ed. 13, 260-263

Haubrich, D. R., Wang, P. F. L., Chippendale, T. \& Proctor, E. (1976) J. Neurochem. 27, 1305-1313

Hoffman, D. R., Cornatzer, W. E. \& Duerre, J. A. (1979) Can. J. Biochem. 57, 56-65
Illingworth, D. R. \& Portman, O. W. (1973) Physiol. Chem. Phys. 5, 365-373

Kates, M. (1960) in Lipid Metabolism (Block, K., ed.), pp. 165-231, Wiley, New York

Kaytal, S. L. \& Lombardi, B. (1978) Pediatr. Res. 12, 952-955

Kennedy, E. P. \& Weiss, S. B. (1956) J. Biol. Chem. 222, 193-214

Ladinsky, H., Consolo, S., Peri, G. \& Garattini, S. (1972) J. Neurochem. 19, 1947-1952

MacFarlane, M. G., Petterson, L. M. B. \& Robinson, R. (1934) Biochem. J. 28, 720-724

Mann, P. J. F. \& Quastel, J. H. (1937) Biochem. J. 31, 869-878

Pardridge, W. M., Cornford, E. M., Braun, L. D. \& Oldendorf, W. M. (1979) in Nutrition and the Brain (Barbeau, A., Growdon, J. \& Wurtman, R., eds.), vol. 5, pp. 25-34, Raven Press, New York

Potter, L. T. \& Murphy, W. (1967) Biochem. Pharmacol. 16, 1386-1388

Robbins, S. J. \& Armstrong, M. J. (1976) Gastroentero$\log y$ 70, 397-402

Rotter, A., Field, P. M. \& Raisman, G. (1979) Brain Res. Rev. 1, 185-205

Saito, M. \& Kanfer, J. (1975) Arch. Biochem. Biophys. $169,318-323$

Sorimachi, M. \& Kataoka, K. (1975) Brain Res. 94, 325-336

Streumer-Svobodova, Z. \& Drahota, Z. (1977) Physiol. Bohemoslov. 26, 334-335

Sundler, R., Arvidson, G. \& Akesson, B. (1972) Biochim. Biophys. Acta 280, 559-568

Weinhold, P. A. \& Sanders, R. (1973) Life Sci. 13, 621629

Wurtman, J. J. (1979) in Nutrition and the Brain (Barbeau, A., Growdon, J. \& Wurtman, R., eds.), vol. 5, pp. 73-81, Raven Press, New York

Zeisel, S. H., Epstein, M. F. \& Wurtman, R. J. (1980) Life Sci. 26, 1827-1831 